\title{
Utilization of YouTube Social Communication Networking in Establishing Indonesian Street Food Opinion
}

\author{
http://dx.doi.org/10.25008/jkiski.v6i1.406
}

\author{
Lidya Wati Evelina $^{1 *}$, Yulianne Safitri ${ }^{2}$ \\ 1,2 Marketing Communication Program, Communication Department \\ Economic and Communication Faculty, Bina Nusantara University \\ Jl. Raya Kebon Jeruk No.27, Jakarta 11530 - Indonesia \\ ${ }^{*}$ Corresponding author: lidiaevelina@binus.ac.id
}

Submitted: February 20, 2021, Revised: March 23, 2021, Accepted: April 29, 2021

Accredited by Kemristekdikti No. 28/E/KPT/2019

\begin{abstract}
In the development of technology in the era of society 5.0, the trend of community activity in social media is oriented towards conversations about YouTube content. The urgency of this research is expected to contribute to the development of communication science, especially for social media activists, especially Indonesian YouTubers, to create Indonesian Street Food content by seeing the phenomenon of foreign YouTubers liking and creating Indonesian Street food content on their YouTubers channel. Discussion on Networking in Establishing The opinion of Indonesian street food that is reviewed on YouTube social media aims to explain foreigner reviews about Indonesian street food from the conversations that occur in the comments. The theory used is the theory of social communication networks, the concept of online community involvement, creative content on YouTube using a qualitative approach. Data collection was carried out using the netnography method obtained from observing content and comments on the YouTube Channel. The findings of this study are that there is intense and funny communication between foreigners regarding terms used in street food in Indonesia, likes and comments on YouTube channels can provide recommendations for foreign tourists to choose Indonesian Street Food when visiting Indonesia. The results of his research opinion were formed from conversations that took place through comments on Indonesian street food content on Luke Martin and Sabrina Davidson's Foreigners YouTube Channel.
\end{abstract}

Keywords: Foreigners; Indonesian street food; opinion; social communication networking; YouTube

\section{Introduction}

Before there was social media, people would share culinary experiences only with their families and closest people and they were done enjoying it. With the development of internet technology that gave birth to social media allows people to share their experiences when enjoying culinary delights to many people when they enjoy the culinary.

For sharing experiences on social media, you can use a blog (Food Blogger), Instagram (Celebrity Culinary) or YouTube (Food Vlogger). For this research, focused on social communication networking that occurs in creative content uploaded on foreigners' YouTube channel which attracts many subscribers.

Indonesian cuisine is known to have a variety of food choices that can be tasted by not only Indonesian food vloggers but also Food Vloggers from other countries. There are some foreign food vloggers who fall in love with Indonesian culinary specialties including Mark Wiens Food Vlogger, The Food Ranger, Miss Mina Oh, Fung Bros Food, and Luke Martin.

Many people like creative content presented by Food Vlogger for several reasons. First, because there is intimacy that the YouTuber offers. Usually YouTubers create their culinary content on the 
dining table or in the comfort of their living room. This indirectly makes the audience as if they were there.

The second reason, viewers who eat alone can feel accompanied by someone if they eat while watching a YouTuber video. The next reason, watching videos on YouTube makes it an outlet for hunger without actually having to eat. Based on the reasons above, which made YouTuber become passionate in creating culinary Creative content on YouTube Channel to earn lots of money.

On the other hand, those who view YouTube content get knowledge of culinary places like recommended Indonesian street food.

From the description of Foreigners creative content about culinary on YouTube channel, it is interesting to be researched specifically about Indonesian street food in Indonesian regions. This study will analyse (1) How many viewers and subscribers of Indonesian Street food content on the Foreigners YouTube channel? (2) How do the comments of the viewers interact with each other and provide recommendations for forming opinions on Indonesian Street food? The results of the study are expected to be able to describe what opinions are formed related to Indonesian street food through the comments on the YouTube channel which are the object of this research.

\section{Theoretical Framework}

This research uses social networking theory, the concept of influential social networking, online community engagement and creative content on YouTube channel which will be describe below

\section{Social Networking Theory}

Community life in the real world and in cyberspace will form social networks based on their interests. One theory that discusses relationships is social networking theory. This theory talks about the interaction of community members who have trust in one another. In social networking there is trust between members governed by norms based on consensus (Ritzer, 2014).

Social networking is based on a desire to exchange information, remind one another and help one another to implement or make choices about something. Relations between members reflect the expected role of each member. Social networks provide ways of collaborating to obtain information; blocking and winning competitions; including regulating and determining a decision (Agusyanto, 2014).

The nature of this social networking is bonding, bridging and linking. This theory assesses that each member has different access to resources, namely wealth, power and information (Agusyanto, 2014).

There are 3 main dimensions of Social Networking, namely (1) interest networks, formed from social relationships based on interests; (2) Power networks, relationships based on the power of a person or social unit to influence people's behaviour and decision making; (3) Emotional networks based on emotions such as love, friendship or family relations and the like (Monge, 2003).

Some research shows that communication that is carried out continuously through social networks can influence the behavior of a person and certain groups in a relatively short time (Burke-Garcia et al., 2017); (Müller, 2018) Therefore, influencers or social media opinion leaders are considered to be important nodes in communication networks, because they can act as leaders, attractors or disseminators of information (Del Fresno García et al., 2016).

The more followers a person has on social media he has, the more widespread the influence he can have on social media societies (De Veirman et al., 2017). Apart from the number of followers, interactions that occur such as conversations in the comments column also determine the formation of opinions (Xiong et al., 2018), sometimes even the formation of opinions through the communication process that occurs social media is even stronger than direct communication (Hampton et al., 2017).

\section{Online Community Engagement}

The purpose of creating creative content on YouTube is to earn revenue. There are many ways that Content Vlogger does to create engagement with viewers. The viewer referred to here is the Food online community. One of them is by sharing YouTube content links on other social media platforms such as Website, Instagram and Facebook.

Social networking sites (SNSs) have become interactive platforms for the marketers and the audience. People have lately become more used to communicate and socialize via the Internet (Carlsson in (Khajuria, 2017)).

Online community engagement can form community loyalty (Han et al., 2019), one of which is through similarity in opinion. People will gather in the same community if they have similarities in opinion.

\section{Content Creatif in YouTube}

In general, creative content on YouTube occurs because of interactions between individuals in the network on a topic that is packaged in an innovative form (Henriksen et al., 2016). 
Based on the article also explained that this can happen because on YouTube the role of gatekeeper is not dominant so that content creators can create more freely by utilizing various forms of communication. Creativity is also assessed in terms of novelty, originality, and experimentation on existing concepts (McDaniel, R., Fanfarelli, J. R., \& Lindgren, 2017); (Wu et al., 2016), in addition to creations in conveying ideas, creations can also be done on technical matters such as taking pictures, camera angles, presentation of writing and communication in the form of words conveyed.

\section{Material and Methodology}

This study discusses social communication networking on YouTube about Indonesian Street food by using a qualitative approach with netnography method which is a text study. Data collection using netnography, collects data obtained from internet-mediated communication from members of a community, including in the form of interaction, collaboration, connection with community members (Kozinets, 2010).

In this study, data from conversations found from the Youtube Channel Foreigners Luke Martin and Sabrina Davidson. This research period was taken by comments from netizens or members of the community formed on the Foreigners YouTube channel from 2018 to 2020 .

The purpose of using this method is to determine the social changes that occur. Data analysis was performed by comparing experiences, taking into account demographic variables such as age, gender and length of time visiting the cyber world (Kozinets, 2010).

After the data is analysed, it is then validated using the triangulation of social communication theory and New Media Theory which suppress engagement among subscribers.

The categories (Dehghani et al., 2016) applied to this study were : (1) Entertainment : to entertaining the viewer; (2) Informative : to shared information; (3) Recommendation: to provide recommendations; (4) Irritation: in the form of comments that can make other people who read feel uncomfortable because they use harsh words and hate speech whether directed directly to the host or not.

\section{Result and Discussion}

YouTube vlogger Luke Martin is the main host of YouTube channel Chopstick Travel with his partner Sabrina, has $804 \mathrm{~K}$ subscribers $(29 / 04 / 20)$ and has uploaded 233 videos since February 10, 2016. The majority of videos are street food from all countries that they have visited including in Taiwan, India, Singapore, Malaysia including Indonesia. The aim is to document the best and most authentic places of local cuisine, with the hope that it can become a reference for travellers who want to taste authentic culinary tours of interesting street food. Luke Martin received an award as Best Food \& Travel Blog from Lux Magazine in 2018 and 2019.

\section{Content Creates Social Communication Networking}

In 2018 and 2020 Luke Martin made 11 (eleven) video content of their experiences tasting food while in Indonesia. This study analyzes 7 (seven) video contents that directly review the tasted street food. The video was made from four regions in Indonesia visited, namely Bali, Jakarta, Yogyakarta and Bukittinggi.

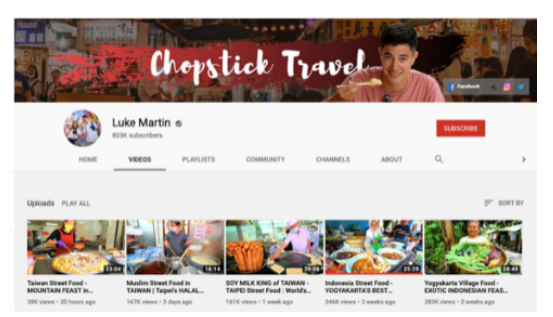

Figure 1. Vlog Chopstick Travel

Source: YouTube Channel Luke Martin (2020).

\section{Indonesian Street Food in Bali}

Episode Title: Grazy Bali Night Market - Best Street Food in Bali + Indonesian Babi Guling posted on May 14, 2018, the food that was tried was fried bananas, chicken satay, pork roll, chicken betutu, and mini martabak at Gianyar Market, Bali. To get to this location, Martin rode a 20-minute scooter from Ubud. This video was viewed 399,272 times, getting Like 5.7 K, Unlike 235 and 766 comments (accessed 29/04/2020, 23.16).

Table 1. Types and amounts of Indonesian food in Bali.

\begin{tabular}{|l|c|c|}
\hline $\begin{array}{c}\text { Category of } \\
\text { Content }\end{array}$ & Comments & $\begin{array}{c}\text { Percentage } \\
(\%)\end{array}$ \\
\hline Information & 145 & 19 \\
\hline Entertainment & 276 & 36 \\
\hline Recommendation & 46 & 6 \\
\hline Irritation & 299 & 39 \\
\hline \multicolumn{1}{|c|}{ Total } & 766 & 100 \\
\hline
\end{tabular}

Source: Research Results (2020)

In this manually calculated content, the majority of comments contain disturbances, in the form of expressions of disapproval over content containing non-halal food (pork roll) and harsh words thrown by the audience in the comment's column related to food prices tasted by Luke Martin. Luke's video reveals that in this market 
food prices are cheap, for Balinese standards there are also cheap.

Many viewers disagree with this statement. According to the audience the price paid by Luke Martin to the seller for some food (10 chicken skewers IDR 50k, 1 pc mini martabak IDR 30k) is much more expensive than usual. Both in Bali or even where they live outside of Bali. Based on the analysis of the disruption comments on this content it can be concluded that opinion has formed that street food in Bali is expensive.

However, the number of comments in the entertainment category is also quite large, the majority in the form of expressions of appreciation for Luke Martin's videos and expressions of excitement for Luke Martin's visit to the location and try their favorite snacks. Comments in the form of majority information contain explaining some of the things delivered by Luke Martin, such as soy sauce, types of martabak, and various kinds of fried food.

There are probably only a few comments that recommend other snacks in Bali because the majority of viewers focus on food prices that are considered high. Based on the results of the analysis, opinions formed on Bali street food have no special snacks, and what makes travelers happy when visiting Bali is not because of street food.

The popularity of YouTube is also influenced by social dynamics, such as the interaction of creators with followers.(Hoiles et al., 2017) Therefore, responses to opinions written by followers in the comments column also need to be responded to by YouTube owners to build closeness in interactions. There are many ways to respond to the opinions in the comments column, one of which is done by the YouTube channel Luke Martin replied by created content related video.

\section{Indonesian Street Food in Yogyakarta}

Episode title Yogyakarta's Best Street Food Guide Crazy, Halal Food Tour in Yogyakarta. This video has a duration of 25:28 uploaded on April 12, 2020 and has been viewed 343,428 times and received $6.9 \mathrm{~K}$ Likes, 139 Unlike and 1,127 comments (accessed 04/29/2020, 23.16).

The food tasted was the famous Lupis Mbah Satinem and was included in the Netflix street food series, Mbah Marto roasted Mangut catfish, Mbah Hadi Javanese noodles, wedang ronde Mbah Palyem and Jos coffee (black coffee with charcoal) at Lik Man coffee shop.

Table 2. Street Food in Yogyakarta

\begin{tabular}{|l|c|c|}
\hline $\begin{array}{l}\text { Category of } \\
\text { Content }\end{array}$ & Comments & $\begin{array}{l}\text { Percentage } \\
(\%)\end{array}$ \\
\hline Information & 361 & $32 \%$ \\
\hline
\end{tabular}

\begin{tabular}{|l|c|c|}
\hline Entertainment & 462 & $41 \%$ \\
\hline Recommendation & 236 & $21 \%$ \\
\hline Irritation & 68 & $6 \%$ \\
\hline Total & 1.127 & $100 \%$ \\
\hline
\end{tabular}

Source: Research Results (2020)

The majority of the comments on this video contain excitement over Luke Martin's arrival in Yogyakarta, praise for the video content, appreciation for the seller, and expressions of the desire of viewers from overseas and other regions of Indonesia to come to taste food at the location after the pandemic ends. Food recommendations that are shared through the YouTube channel can affect the viewer's food preferences (Kang et al., 2020).

The audience also informed many of the details of the food that was tasted until the history of the meal and the audience gave recommendations to each other on other foods in Yogyakarta. Most disturbance comments contain comments that are not relevant to the content presented, and some are negative comments regarding the cleanliness of the food being eaten.

\section{Indonesian Street Food in Jakarta Series (3 episodes)}

Episode 1 Title: Indonesian Street Food tour in Jakarta- Seafood + Padang Street Food - Rare Egg Crust + Best BBQ.

This video was uploaded on May 18, 2018, has been watched 319,684 times and received 5.6K feedback likes, $127 \mathrm{~K}$ unlike and 636 comments.

Table 3. Street Food in Jakarta ep.1

\begin{tabular}{|l|c|c|}
\hline $\begin{array}{c}\text { Category of } \\
\text { Content }\end{array}$ & Comments & $\begin{array}{c}\text { Percentage } \\
(\%)\end{array}$ \\
\hline Information & 83 & $13 \%$ \\
\hline Entertainment & 324 & $51 \%$ \\
\hline Recommendation & 197 & $31 \%$ \\
\hline Irritation & 32 & $5 \%$ \\
\hline \multicolumn{1}{|c|}{ Total } & 636 & $100 \%$ \\
\hline
\end{tabular}

Source: Research Results (2020)

This video is 27:05 minutes long, located in central Jakarta and North Jakarta. The majority of viewers are entertained with this video. Luke and Sabrina for the first time in Jakarta, the audience welcomed with a welcome in Jakarta and recommended food places to visit.

The food tasted in this video is first serikaya bread and coffee at Sabang 16 coffee shop. In the video, it turns out that toast and coffee are Luke's favourite menus for breakfast. The audience gave information about serikaya, ranging from how to make it to taste. They then went to the old city and when walking towards RM Padang Merdeka they stopped for a while to taste the egg Crust. Lunch at 
Padang Merdeka ordered 9 different types of menus.

Viewers from Indonesia were entertained to see Luke tasting jengkol that's ended lot of amusing comments from Indonesian viewers. Overseas viewers were satisfied watching this video because Luke described the food in detail, some who had never been to Jakarta planned to follow Luke's route on this video.

Overseas viewers who followed Luke's route to Jakarta said they were satisfied. Luke and Sabrina moved locations using Gojek and the first time they tried Gojek motorcycles. Luke recommends using motorbike taxi because of heavy Jakarta traffic. The last meal is grilled fish at Muara Angke Fish Market.

Episode 2 Title: Huge Indonesian Goat Fried Rice - Crazy street Food in Jakarta, Indonesia.

This video is the first video from the Jakarta series, uploaded on May 23, 2018, was viewed 197,770 times and received 4.7K feedback likes, unlike 103 and 514 comments (accessed 04/30/2012 at 12:10).

Table 4. Street Food in Jakarta ep.2

\begin{tabular}{|l|c|c|}
\hline $\begin{array}{c}\text { Category of } \\
\text { Content }\end{array}$ & Comments & $\begin{array}{c}\text { Percentage } \\
(\%)\end{array}$ \\
\hline Information & 64 & $12 \%$ \\
\hline Entertainment & 328 & $64 \%$ \\
\hline Recommendation & 103 & $20 \%$ \\
\hline Irritation & 19 & $4 \%$ \\
\hline \multicolumn{1}{|c|}{ Total } & 514 & $100 \%$ \\
\hline
\end{tabular}

Source: Research Results (2020)

The majority of comments on this video expressions that they are entertained by the expression displayed on Luke Martin's video when trying several types of food for the first time. Viewers from related countries (PhilippinesMalaysia-Thailand) commented on how similar the conditions of the streets, the market atmosphere in Jakarta to in their countries, as well as the similarities in the food. Some provide recommendations for other food places in Jakarta, some recommend similar menus when visiting their country.

Episode 3 Title: Muslim Street Food in Jakarta - Spicy Indonesian Street Food - Best BBQ + Streed Food in Indonesia. This video was uploaded on May 29, 2018T and has been viewed 280,271 times with $5.5 \mathrm{~K}$ feedback likes, 146 unlike and 709 comments.

Table 5. Street Food in Jakarta ep.3

\begin{tabular}{|l|c|c|}
\hline $\begin{array}{c}\text { Category of } \\
\text { Content }\end{array}$ & Comments & $\begin{array}{c}\text { Percentage } \\
(\%)\end{array}$ \\
\hline Information & 71 & $10 \%$ \\
\hline Entertainment & 432 & $61 \%$ \\
\hline
\end{tabular}

\begin{tabular}{|c|c|c|}
\hline Recommendation & 99 & $14 \%$ \\
\hline Irritation & 71 & $10 \%$ \\
\hline Total & 709 & $100 \%$ \\
\hline
\end{tabular}

Source: Research Results (2020)

In this video the majority of the audience was entertained and commented on Luke Martin's expression while tasting the food, explaining the taste of the food and the type of food that was tasted, namely the bopet mini Padang cuisine, konro bakar karebosi soup, uduk rice kota Intan and martabak Pecenongan.

The majority of the audience felt entertained by commenting on the very large portion of butter in Martabak, with lots of cheese, sprinkle chocolate, nuts and sweetened condensed milk. Some other viewers said it was very good although not good for health. Some viewers clarified that the price of uduk rice which Luke considered expensive was correct. Video entertained the audience, especially those from Indonesia, a few snippets of pictures showing local people conversing with local languages and if we understand the meaning is very funny.

\section{Indonesian Street Food in Bukittinggi}

Episode Title: Bukittingi's Best Street Food Guide! Crazy minang food Guide! crazy minang food.

Episode Title: Bukittinggi's Best Street Food Guide! Crazy Minang Food In West Sumatra!. This video has a duration of 18:31 minutes, uploaded on March 15, 2020, has been viewed 703,300 times and received $12 \mathrm{~K}$ likes, unlikes 366 and 1,427 comments.

Table 6. Street Food in Bukittinggi

\begin{tabular}{|c|c|c|}
\hline $\begin{array}{c}\text { Category of } \\
\text { Content }\end{array}$ & Comments & $\begin{array}{c}\text { Percentage } \\
(\%)\end{array}$ \\
\hline Information & 143 & $10 \%$ \\
\hline Entertainment & 856 & $60 \%$ \\
\hline Recommendation & 428 & $30 \%$ \\
\hline Irritation & 0 & 0 \\
\hline Total & 1.427 & $100 \%$ \\
\hline
\end{tabular}

Source: Research Results (2020)

The locations visited in this video are Sate Mak Syukur Padang Panjang, Bika Talago, Kapau Rice Uni Lis los Lambuang Bukit Tinggi, juice stalls near Jam Gadang, and durian are alongside the road to Padang.

In this video, there is no irritating comments were found, the majority of the comments were from viewers who were entertained by the uploaded videos, praised their shooting techniques, and appreciated the explanation of the food tasted. 
The audience commented on the taste of West Sumatra cuisine which is hot and rich in spices. They were surprised Luke martin could overcome the spicy taste. Viewers from several other countries who have tried West Sumatra cuisine argue that the cuisine is even more spicy and richer in flavour than Indian cuisine. The audience also recommended other places to eat and the types of cuisine of West Sumatra that are worth trying.

\section{Indonesia Street Food Opinion}

All regions in Indonesia, have local street food, generally Indonesian street food is rich in spices. Each region has a unique taste, for example Yogyakarta, almost all of the food tastes sweet. While Jakarta, its savoury. Bukittinggi and all-over West Sumatera, almost all of its food contains coconut milk.

From the results of the research above, overall opinion of Indonesian Street Food in Bali, Yogyakarta, Jakarta and Bukittinggi contains content Entertainment with the reason that each location has a unique way of eating, conversation between Luke Martin (Foreigner) with local sellers.

Based on observations, opinions formed from viewers' comments posting create experience in enjoying Indonesian Street food. That brought entertainment for the food
In recent years Indonesian people have been flooded with foreign street food, various brand of teas, bubble drinks, ramen, topokki and etc.

The presence of this vlog has succeeded in making Indonesian viewers appreciate the rich culinary taste of Indonesia as good as the international street foods. Hopefully, that this can improve the sustainability of street food in Indonesia to become winners in our own country.

\section{Social Communication Networking on YouTube Model}

A comment column where viewers share their opinion on the videos they watch, video creators and other viewers can also find useful information (Khan et al., 2016), interest to tried the recommendations shared via video, forming opinion (Kim \& Hastak, 2018), entertaining (Lou \& Xie, 2020), although sometimes the comments can be irritating (Dehghani et al., 2016).

From the results and investigation of this study, this research purpose a model of Social Communication Networking on YouTube model as below:

The above model shows that the content category can shape the communication of social networks which in this study occurred in comments on YouTube videos in Luke Martin's channel.

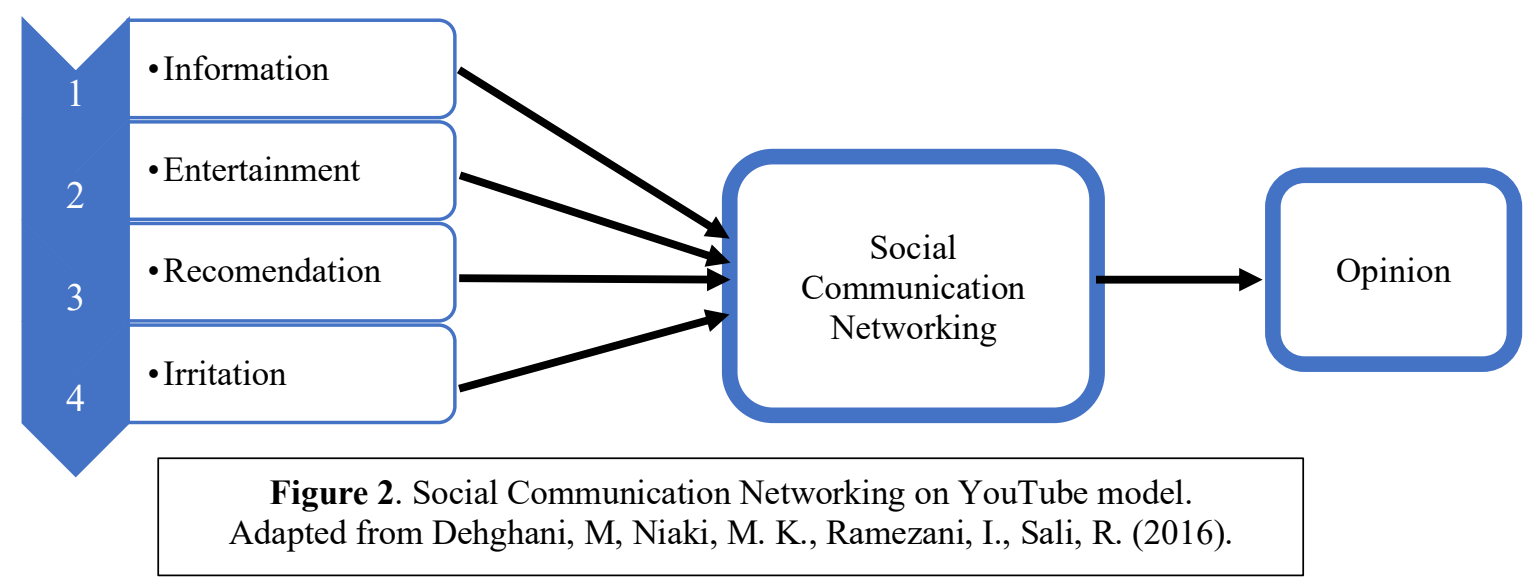

Vlogger itself and also managed to entertain the viewers. The video even aroused the appetite to enjoy Indonesian Street Food directly. Some of them also recommend to Vloggers to try tasting Indonesian Street Food in other areas. This vlog has succeeded in exploring street food that may be forgotten by Indonesians due to the rise of foreign street food brands that have been entering Indonesia in recent years.
Interactions that occur in the comments column on YouTube can form opinions from video viewers that have been concluded in the research results above.

\section{Conclusions}

Research on Utilization of YouTube Social Communication Networking Establishing Indonesian Street Food Opinion produces Social Communication Networking on YouTube Model. This research successfully answered the research question. 
Creative content made by Food Vlogger Foreigner Interaction averages above 500 comments per post.

The lowest is 514 comments from the content entitled Huge Indonesia Goat Fried Rice- Crazy street Food in Jakarta. Highest comment Bukittinggi's Best Street Food Guide! Crazy Minang Food in West Sumatra.

Opinion is formed from the conversation, most viewers from people from the other country (Foreigners) and Indonesians feel happy with the video, so they are interested in trying the food.

The limitations of this study only see one YouTube Channel among several food vloggers who review Indonesian food. YouTube Channel was chosen because it consistently reviews street food around the world, while other food vloggers do not.

It is recommended for further research to be able to compare opinions formed on street food in Indonesia from local food vloggers even though its limited. Further research also recommended to see the effect of the YouTube video postings on costumer's intention to buy in Indonesian street food.

\section{References}

Agusyanto, R. (2014). Jaringan Sosial dalam Organisasi. Raja Grafindo Persada.

Burke-Garcia, A., Berry, C. N., Kreps, G. L., \& Wright, K. B. (2017). The Power \& Perspective of Mommy Bloggers: Formative Research with Social Media Opinion Leaders about HPV Vaccination. Proceedings of the 50th Hawaii International Conference on System Sciences (2017), 1932-1941. https://doi.org/10.24251/hicss.2017.234

De Veirman, M., Cauberghe, V., \& Hudders, L. (2017). Marketing through instagram influencers: The impact of number of followers and product divergence on brand attitude. International Journal of Advertising, 36(5), 798-828. https://doi.org/10.1080/02650487.2017.1348 035

Dehghani, M., Niaki, M. K., Ramezani, I., \& Sali, R. (2016). Evaluating the influence of YouTube advertising for attraction of young customers. Computers in Human Behavior, 59 , 165-172. https://doi.org/10.1016/j.chb.2016.01.037

Del Fresno García, M., Daly, A. J., \& SánchezCabezudo, S. S. (2016). Identificando a los nuevos influyentes en tiempos de Internet:
Medios sociales y análisis de redes socials. Revista Espanola de Investigaciones Sociologicas, 153(March), 23-42. https://doi.org/10.5477/cis/reis.153.23

Hampton, K. N., Shin, I., \& Lu, W. (2017). Social media and political discussion: when online presence silences offline conversation. Information Communication and Society, 20(7), $1090-1107$. https://doi.org/10.1080/1369118X.2016.1218 526

Han, J., Jun, M., \& Kim, M. (2019). Impact of online community engagement on community loyalty and social well-being. Social Behavior and Personality, 47(1), 1-8. https://doi.org/10.2224/sbp.7545

Henriksen, D., Hoelting, M., \& the Deep-Play Research Group. (2016). A Systems View of Creativity in a YouTube World. TechTrends, 60(2), 102-106. https://doi.org/10.1007/s11528-016-0047-2

Hoiles, W., Aprem, A., \& Krishnamurthy, V. (2017). Engagement and Popularity Dynamics of YouTube Videos and Sensitivity to MetaData. IEEE Transactions on Knowledge and Data Engineering, 29(7), 1426-1437. https://doi.org/10.1109/TKDE.2017.2682858

Kang, E. K., Lee, J., Kim, K. H., \& Yun, Y. H. (2020). The popularity of eating broadcast: Content analysis of "mukbang" YouTube videos, media coverage, and the health impact of "mukbang" on public. Health Informatics Journal, 26(3), 2237-2248. https://doi.org/10.1177/1460458220901360

Khajuria, I. (2017). A Study of User-Generated Content on Social Networking Sitesand its Impact on Consumer-Based Brand Equity Constructs. 17(1).

Khan, A. U. R., Khan, M., \& Khan, M. B. (2016). Naïve Multi-label Classification of YouTube Comments Using Comparative Opinion Mining. Procedia Computer Science, 82(March), 57-64. https://doi.org/10.1016/j.procs.2016.04.009

Kim, J., \& Hastak, M. (2018). Social network analysis: Characteristics of online social networks after a disaster. International Journal of Information Management, 38(1), 86-96.

https://doi.org/10.1016/j.ijinfomgt.2017.08.0 03

Kozinets, R. (2010). Netnography: Doing Ethnographic Research Online. Sage Publications Ltd.

Lou, C., \& Xie, Q. (2020). Something social, something entertaining? How digital content marketing augments consumer experience and 
brand loyalty. International Journal of Advertising, $\quad 0(0), \quad 1-27$. https://doi.org/10.1080/02650487.2020.1788 311

McDaniel, R., Fanfarelli, J. R., \& Lindgren, R. (2017). Creative Content Management: Importance, Novelty, and. 60(2), 204-205.

Monge, P. R. (2003). Theories Communication Network. Oxford University.

Müller, A. (2018). Omnichannel Branding. In Omnichannel Branding. Springer Fachmedien Wiesbaden. https://doi.org/10.1007/978-3658-21450-0

Ritzer, G. (2014). Teori Sosiologi Modern (7th editio). Kencana Prenadamedia Group.

Wu, Y. L., Li, E. Y., \& Chang, W. L. (2016). Nurturing user creative performance in social media networks: An integration of habit of use with social capital and information exchange theories. Internet Research, 26(4), 869-900. https://doi.org/10.1108/IntR-10-2014-0239

Xiong, Y., Cheng, Z., Liang, E., \& Wu, Y. (2018). Accumulation mechanism of opinion leaders' social interaction ties in virtual communities: Empirical evidence from China. Computers in Human Behavior, 82, 81-93. https://doi.org/10.1016/j.chb.2018.01.005

Agusyanto, R. (2014). Jaringan Sosial Dalam Organisasi. Raja Grafindo Persada.

Burke-Garcia, A., Berry, C. N., Kreps, G. L., \& Wright, K. B. (2017). The Power \& Perspective of Mommy Bloggers: Formative Research with Social Media Opinion Leaders about HPV Vaccination. Proceedings of the 50th Hawaii International Conference on System Sciences (2017), 1932-1941. https://doi.org/10.24251/hicss.2017.234

De Veirman, M., Cauberghe, V., \& Hudders, L. (2017). Marketing through instagram influencers: The impact of number of followers and product divergence on brand attitude. International Journal of Advertising, $36(5)$, 798-828. https://doi.org/10.1080/02650487.2017.1348 035

Dehghani, M., Niaki, M. K., Ramezani, I., \& Sali, R. (2016). Evaluating the influence of YouTube advertising for attraction of young customers. Computers in Human Behavior, 59 , 165-172. https://doi.org/10.1016/j.chb.2016.01.037

Del Fresno García, M., Daly, A. J., \& SánchezCabezudo, S. S. (2016). Identificando a los nuevos influyentes en tiempos de Internet: Medios sociales y análisis de redes socials. Revista Espanola de Investigaciones Sociologicas, 153(March), 23-42. https://doi.org/10.5477/cis/reis.153.23

Hampton, K. N., Shin, I., \& Lu, W. (2017). Social media and political discussion: when online presence silences offline conversation. Information Communication and Society, 20(7), 1090-1107. https://doi.org/10.1080/1369118X.2016.1218 526

Han, J., Jun, M., \& Kim, M. (2019). Impact of online community engagement on community loyalty and social well-being. Social Behavior and Personality, 47(1), 1-8. https://doi.org/10.2224/sbp.7545

Henriksen, D., Hoelting, M., \& the Deep-Play Research Group. (2016). A Systems View of Creativity in a YouTube World. TechTrends, 60(2), 102-106. https://doi.org/10.1007/s11528-016-0047-2

Hoiles, W., Aprem, A., \& Krishnamurthy, V. (2017). Engagement and Popularity Dynamics of YouTube Videos and Sensitivity to MetaData. IEEE Transactions on Knowledge and Data Engineering, 29(7), 1426-1437. https://doi.org/10.1109/TKDE.2017.2682858

Kang, E. K., Lee, J., Kim, K. H., \& Yun, Y. H. (2020). The popularity of eating broadcast: Content analysis of "mukbang" YouTube videos, media coverage, and the health impact of "mukbang" on public. Health Informatics Journal, 26(3), 2237-2248. https://doi.org/10.1177/1460458220901360

Khajuria, I. (2017). A Study of User-Generated Content on Social Networking Sitesand its Impact on Consumer-Based Brand Equity Constructs. 17(1).

Khan, A. U. R., Khan, M., \& Khan, M. B. (2016). Naïve Multi-label Classification of YouTube Comments Using Comparative Opinion Mining. Procedia Computer Science, 82(March), 57-64. https://doi.org/10.1016/j.procs.2016.04.009

Kim, J., \& Hastak, M. (2018). Social network analysis: Characteristics of online social networks after a disaster. International Journal of Information Management, 38(1), 86-96.

https://doi.org/10.1016/j.ijinfomgt.2017.08.0 03

Kozinets, R. (2010). Netnography: Doing Ethnographic Research Online. Sage Publications Ltd.

Lou, C., \& Xie, Q. (2020). Something social, something entertaining? How digital content marketing augments consumer experience and brand loyalty. International Journal of Advertising, $\quad 0(0), \quad 1-27$. https://doi.org/10.1080/02650487.2020.1788 
311

McDaniel, R., Fanfarelli, J. R., \& Lindgren, R. (2017). Creative Content Management: Importance, Novelty, and. 60(2), 204-205.

Monge, P. R. (2003). Theories Communication Network. Oxford University.

Müller, A. (2018). Omnichannel Branding. In Omnichannel Branding. Springer Fachmedien Wiesbaden. $\quad$ https://doi.org/10.1007/978-3658-21450-0

Ritzer, G. (2014). Teori Sosiologi Modern (7th editio). Kencana Prenadamedia Group.

Wu, Y. L., Li, E. Y., \& Chang, W. L. (2016). Nurturing user creative performance in social media networks: An integration of habit of use with social capital and information exchange theories. Internet Research, 26(4), 869-900. https://doi.org/10.1108/IntR-10-2014-0239

Xiong, Y., Cheng, Z., Liang, E., \& Wu, Y. (2018). Accumulation mechanism of opinion leaders' social interaction ties in virtual communities: Empirical evidence from China. Computers in Human Behavior, 82, 81-93.

https://doi.org/10.1016/j.chb.2018.01.005 